\title{
Chemical Composition and Comparative Antibacterial Properties of Basil Essential Oil against Clinical and Standard Strains of Campylobacterspp.
}

\author{
Aysegul Mutlu-Ingok $k^{1,2 *}$, Burcu Firtinn', Funda Karbancioglu-Guler ${ }^{1}$ \\ 1 Istanbul Technical University, Faculty of Chemical and Metallurgical Engineering, Department of Food Engineering, \\ Istanbul, Turkey. \\ 2 Duzce University, Akcakoca Vocational School, Food Technology Department, Duzce, Turkey.
}

\begin{abstract}
This study has aimed to evaluate comparative antibacterial activity of basil essential oil against clinical and standard isolates of Campylobacter spp. by different methods as agar well diffusion, agar and broth dilution methods. Gas Chromatography (GC) and Gas Chromatography/Mass Spectrometry (GC/MS) analysis were also examined to determine the chemical composition of the tested essential oil. GC/ MS analysis showed that, basil essential oil was predominated by methyl chavicol (86.6\%) followed by 1,8 -cineole $(2.8 \%)$ and $\alpha$-bergamotene $(2.4 \%)$. Although, inhibition zone diameters were in the range of $10.9 \pm 0.8$ to $21.8 \pm 1.4 \mathrm{~mm}$, higher MIC values were obtained against clinical strains compared with standard ones. Due to the differences in antimicrobial resistance of the clinical and standard strains, antimicrobial activity tests should be carried out with isolates from different sources.
\end{abstract}

Keywords: Basil essential oil, Chemical composition, Agar well diffusion, Broth microdilution, Agar dilution.

\section{INTRODUCTION}

Campylobacter spp. is considered to be the most common bacterial cause of human gastroenteritis in the world ${ }^{1}$. Food-borne Campylobacter infections are considered to be caused by animal origin foods, mainly poultry and poultry products. Besides poultry, raw milk, pork, beef, lamb and seafood are responsible of Campylobacter infections ${ }^{2}$. The antimicrobial resistance of

\footnotetext{
*Corresponding Author: Aysegul Mutlu-Ingok, e-mail: aysegulmutlu@duzce.edu.tr Aysegul Mutlu-Ingok ORCID Number: 0000-0001-9571-0053

Burcu Firtin ORCID Number: 0000-0002-4633-9582

Funda Karbancioglu-Guler ORCID Number: 0000-0001-6576-0084

(Received 15 January 2019, accepted 23 February 2019)
} 
thermophilic campylobacters, including Campylobacter jejuni and C. coli has been identified especially to tetracyclines and fluoroquinolones at important levels in many different parts of the world ${ }^{1,3}$. Using chemical compounds have limits because of their carcinogenic effects, acute toxicity, and environmental hazard potential ${ }^{4}$. Increasing resistance to currently used antimicrobials and consumer concerns about using chemical preservatives lead to investigation of alternative strategies to prevent and control these microorganisms. Despite the high number of studies on the antimicrobial effects of essential oils (EOs), most studies have focused on pathogenic bacteria like Staphylococcus aureus, Escherichia coli, and Bacillus cereus ${ }^{5}$.

Essential oils which were synthesized naturally in different plant parts are complex volatile compounds. They can be extracted from medicinal aromatic plants and have strong antimicrobial activity against various bacterial, fungal, and viral pathogens. In addition to their antibacterial properties, they have antiviral, antimycotic, antitoxigenic, antiparasitic, insecticidal, antimutagenicity, cytoprotective, moderation of insulin secretion analgesic, neuroprotective, antioxidant, antiproliferative proapoptotic anxiolytic-like activities ${ }^{6}$. Their wide range of antimicrobial activity was a result of different types of aldehydes, phenolics, terpenes, and other antimicrobial compounds ${ }^{4}$. Mechanism of antimicrobial action is still lacking although a few studies have been elucidated ${ }^{7}$.

Basil is the common name for the culinary herb Ocimum basilicum of the family Lamiaceae (Labiatae). Although the basil essential oil's antibacterial activity is associated with its high content in linalool and estragole, antimicrobial spectrum is restricted to specific bacteria other than Campylobacter spp. ${ }^{8}$ Although in few studies antimicrobial activity of basil essential oil against Campylobacter spp. has been mentioned ${ }^{9,10}$, our literature review revealed that the differences of antimicrobial effects against clinical and standard Campylobacter isolates were not discussed.

In this study, it was aimed to evaluate comparative antibacterial activity of basil essential oil against clinical and standard isolates of Campylobacter jejuni and Campylobacter coli by different methods as agar well diffusion, agar and broth dilution methods. Gas Chromatography (GC) and Gas Chromatography/ Mass Spectrometry (GC/MS) analyses also examined the chemical composition of the tested EO.

\section{METHODOLOGY}

\section{Bacterial culture and essential oils}

The antimicrobial activity of the cold pressed basil essential oil was tested 
against clinical Campylobacter jejuni, Campylobacter coli identified by Matrix- Assisted Laser Desorption/Ionization time- of- flight Mass Spectrometry (MALDI TOF MS) ${ }^{11}$ and standard Campylobacter jejuni (ATCC 33660), Campylobacter coli (NCTC 12525). Basil essential oil was obtained in food grade form from "International Flavors \& Fragrances (IFF)", Gebze, Kocaeli (Turkey). Dilutions were made in 10\% dimethyl sulfoxide (DMSO, Merck). Before analysis, basil essential oil was sterilized by filtration through $0.22 \mu \mathrm{m}$ filters (Minisart ${ }^{\circledR}$ Syringe Filter, Sartorius Stedim Biotech GmbH, Germany) and stored in dark at $4{ }^{\circ} \mathrm{C}$.

\section{Gas Chromatography (GC)}

Essential oils were analyzed by GC-FID using an Agilent 7890B GC (Agilent, Palo Alto, CA) with a flame ionization detector (FID). The chromatographic separation was accomplished using an Agilent HP- Innowax column (6o m x $0.25 \mathrm{~mm} \emptyset$, with $0.25 \mu \mathrm{m}$ film thickness) with a helium as a carrier gas (0.7 $\mathrm{mL} /$ minute). GC oven temperature was kept at $60^{\circ} \mathrm{C}$ for $10 \mathrm{~min}$ and programmed to $220{ }^{\circ} \mathrm{C}$ at a rate of $4{ }^{\circ} \mathrm{C} /$ minute and then kept constant at $220{ }^{\circ} \mathrm{C}$ for 10 min and programmed to $240{ }^{\circ} \mathrm{C}$ at a rate of $1{ }^{\circ} \mathrm{C} /$ minute. The injector and flame ionization detector temperatures were adjusted to $250{ }^{\circ} \mathrm{C}$. The relative percentage amounts of the separated compounds were calculated from FID chromatograms.

\section{Gas Chromatography-Mass Spectrometry (GC/MS)}

The essential oils were analyzed by GC/MS using an Agilent 7890B GC coupled with a 5977B MSD (Agilent, Palo Alto, CA). The same column and analytical conditions were used for both GC/MS and GC/FID. The mass range was recorded from $\mathrm{m} / \mathrm{z} 35$ to 425 . The injector temperature was adjusted to $250^{\circ} \mathrm{C}$. MS were recorded at $70 \mathrm{eV}$. Alkanes were used as reference points in the calculation of relative retention indices (RRI). The components of EOs were identified by using Wiley 9- Nist 11 Mass Spectral Database and standard Alkan series (C7-C40).

\section{Agar-well diffusion assay}

Inhibition zone diameters were determined using previously described method with slight modifications ${ }^{12}$. Bacterial inoculum was prepared in Mueller-Hinton Broth (MHB, Merck, Darmsdat, Germany) for standard isolate and MHB with $5 \%$ horse blood for clinical isolate and incubated at $42{ }^{\circ} \mathrm{C}$ for $48 \mathrm{~h}$ under microaerophilic conditions created by Anaerocult ${ }^{\circledR}$ C (Merck, Darmsdat, Germany). Concentrations of bacterial suspensions were adjusted to approximately $10^{8} \mathrm{cfu} / \mathrm{mL}$ and $100 \mu \mathrm{L}$ of culture suspension was spreaded on Camp- 
ylobacter Blood-Free Selective Agar Base medium (modified CCDA, Merck, Darmsdat, Germany) for standard isolate, Mueller-Hinton Agar (MHA, Merck, Darmsdat, Germany) medium with $5 \%$ horse blood for clinical isolate. Three wells were cut out of agar and filled with $5 \mu \mathrm{L}, 10 \mu \mathrm{L}$ and $20 \mu \mathrm{L}$ of basil EO. The inoculated plates were incubated at $42{ }^{\circ} \mathrm{C}$ for $48 \mathrm{~h}$ under microaerophilic conditions. After incubation, inhibition zone diameters were measured. All experiments were performed in triplicate. Zones of inhibition (including the $6 \mathrm{~mm}$ of the well) were expressed as mean values with \pm standard deviation.

\section{Broth microdilution assay}

Broth microdilution method was used to determine the minimum inhibition concentrations (MICs), which was described previously by Wiegand et al. ${ }^{13}$. Stock solution was prepared in $10 \%$ DMSO and two-fold serial dilutions of EO were prepared. After sub-culturing in MHB, bacterial concentration was adjusted to approximately $10^{8} \mathrm{cfu} / \mathrm{mL}$. The 96 -well plates were prepared by dispensing, into each well, $95 \mu \mathrm{L}$ of MHB, $100 \mu \mathrm{L}$ of EO and $5 \mu \mathrm{L}$ of the inoculants. The final volume in each well was $200 \mu \mathrm{L}$. The microplates were incubated at $42{ }^{\circ} \mathrm{C}$ for $24 \mathrm{~h}$ under microaerophilic conditions. MIC values were determined spectrophotometrically by measuring the optical density at an absorbance of 600 nm (Synergy HT, BioTek Instruments Inc., Winooski, VT, USA). Negative controls (involving $195 \mu \mathrm{L}$ of MHB and $5 \mu \mathrm{L}$ of inoculum but no EO) for each microorganism and sterility controls (involving $100 \mu \mathrm{L}$ MHB and $100 \mu \mathrm{L}$ EO but no inoculum) for each EO concentrations were prepared.

\section{Agar dilution method}

For clinical strains, to determine minimum inhibitory concentrations (MICs), agar dilution method according to Stepanović et al. ${ }^{14}$ was used with slight modifications. This method based on preparation of MHA with $5 \%$ horse blood with the additions of $1 \%$ Tween 20 and different concentration of essential oils after sterilization of agar. Test plates were prepared with $19 \mathrm{~mL}$ of MHA, and 1 $\mathrm{mL}$ of two-fold dilutions of essential oils. After adjusting bacterial concentration approximately to $10^{8} \mathrm{cfu} / \mathrm{mL}, 10 \mu \mathrm{L}$ of culture suspension was inoculated to agar plates. Plates were incubated for $48 \mathrm{~h}$ at $42{ }^{\circ} \mathrm{C}$ in microaerophilic conditions. The MICs were defined as the lowest concentration of essential oils that inhibited visible growth of microorganisms..$^{14}$

\section{RESULTS AND DISCUSSION}

The chemical composition of the basil EO determined with GC/MS is given in Table 1. The main compound identified in the basil essential oil was methyl chavicol (86.6\%). These results are consistent with those reported in the lite- 
rature. Differences of constituents and their amounts may be related with the geographical origin of the plant, different parts of plants, extraction method and season of harvest ${ }^{15}$.

Table 1. Chemical compositions of basil essential oil.

\begin{tabular}{|l|l|l|l|}
\hline No & Compound & $\mathbf{R}^{\mathbf{a}}$ & Peak area (\%) \\
\hline 1 & 1,8-Cineole & 1220 & 2.8 \\
\hline 2 & a-Bergamotene & 1605 & 2.4 \\
\hline 3 & Methyl chavicol & 1701 & 86.6 \\
\hline Total & & & 91.8 \\
\hline
\end{tabular}

a: Retention index was calculated for all volatile constituents using a homologous series of n-alkanes C7- C40, b: Peak area obtained by GC-FID.

Although different chemical profiles of basil essential oil were reported in literature, methyl chavicol with high citral contents (methyl chavicol/citral) was previously detected as a "new chemo type" in the Turkish basils ${ }^{16}$. In addition to geological origin, chemical constituents varied with different seasons ${ }^{17}$. Generally, the chemical composition profile of basil essential oil confirms previous studies. Methyl chavicol was reported as major constituent in India $(78.3 \%)^{18}$. In another study, three chemotypes of Ocimum basilicum (O. basilicum) were identified as a major methyl chavicol-rich type ( $>65 \%)$, a methyl chavicol (55\%)-linalool (20-30\%) type, a linalool (42-45\%) and eugenol (15\%) type $^{19}$. For this respect, $O$. basilicum used in this study was in methyl chavicolrich type with $86.6 \%$ methyl chavicol. High content of methyl chavicol was also confirmed by Vieira and Simon ${ }^{20}$ with $47 \%$ methyl chavicol content.

The inhibition zone diameters measured ranged from $12.3 \pm 1.6$ to $21.8 \pm 1.4 \mathrm{~mm}$ and $10.9 \pm 0.8$ to $20.4 \pm 2.4 \mathrm{~mm}$ for clinical and standard Campylobacter isolates, respectively (Table 2). Considering the all results, mean inhibiton zone diameter was $15.94 \pm 1.55 \mathrm{~mm}$. Similar to current study, mean zone diameters were reported as $12.48 \mathrm{~mm}$ and $\mathbf{1 3 . 2} \mathrm{mm}$ against gram positive and gram negative bacteria, respectively ${ }^{21}$. Smaller inhibition zones were also reported by Predoi et al. ${ }^{22}$ as 7-10 mm against Escherichia coli, Staphylococcus aureus and methicillin-resistant Staphylococcus aureus. In literature, inhibition zone diameters were varied depending on different extracts. It was reported that although methanol extracts showed inhibition zones against Pseudomonas aeruginosa, Shigella sp., Listeria monocytogenes, Staphylococcus aureus and two different strains of Escherichia coli, chloroform and acetone extracts of $O$. basilucum had no effect ${ }^{23}$. 
Poor solubility and high volatility of essential oils limit the usage of diffusion tests. It is suggested to use agar or broth dilution methods for true antimicrobial activity evaluation ${ }^{24}$. With this respect, in this study, in vitro antimicrobial activity of basil essential oil was not tested only by agar diffusion method but also dilution methods against clinical and standard isolates of Campylobacter spp. (Table 2). It was reported that both agar dilution and broth microdilution methods were equally suitable against Campylobacter spp. and highly correlated $^{25}$. In this study, since broth microdilution method did not give any results against clinical strains, agar dilution method was used by taking this perspective into consideration. Tested essential oil displayed varying degree of antibacterial activity with MIC values ranging from 105.16 to $1787.7 \mu \mathrm{g} / \mathrm{mL}$. Interestingly, MIC values against clinical ones were higher than standard isolates. Higher MIC values indicate that clinical strains are more resistant than standard strains against basil essential oil.

Table 2. Antimicrobial activity of basil essential oil against Campylobacter spp.

\begin{tabular}{|c|c|c|c|c|}
\hline \multirow{3}{*}{ Isolate } & \multicolumn{3}{|c|}{ Amount $(\mu \mathrm{L})$} & \multirow[t]{2}{*}{ MIC $(\mu \mathrm{g} / \mathrm{mL})$} \\
\hline & $5 \mu \mathrm{L}$ & $10 \mu \mathrm{L}$ & $20 \mu \mathrm{L}$ & \\
\hline & \multicolumn{4}{|c|}{ Inhibition zone diameter (mm) } \\
\hline $\begin{array}{l}\text { C. jejuni (Clinical) } \\
\text { Streptomycin }\end{array}$ & $\begin{array}{l}N A^{a} \\
38.0 \pm 1.8\end{array}$ & $\begin{array}{l}13.0 \pm 2.2 \\
40.0 \pm 2.4\end{array}$ & $\begin{array}{l}20.1 \pm 1.6 \\
45.0 \pm 1.4\end{array}$ & $\begin{array}{l}1787.7 \\
\mathrm{NT}^{\mathrm{c}}\end{array}$ \\
\hline $\begin{array}{l}\text { C.coli (Clinical) } \\
\text { Streptomycin }\end{array}$ & $\begin{array}{l}\text { NA } \\
32.0 \pm 1.4\end{array}$ & $\begin{array}{l}12.3 \pm 1.6 \\
38.0 \pm 1.4\end{array}$ & $\begin{array}{l}21.8 \pm 1.4 \\
40.0 \pm 1.3\end{array}$ & $\begin{array}{l}889.08 \\
\text { NT }\end{array}$ \\
\hline $\begin{array}{l}\text { C. jejuni (ATCC 33560) } \\
\text { Streptomycin }\end{array}$ & $\begin{array}{l}\text { NA } \\
21.3 \pm 2.1\end{array}$ & $\begin{array}{l}10.9 \pm 0.8 \\
24.7 \pm 1.5\end{array}$ & $\begin{array}{l}20.4 \pm 2.4 \\
30.0 \pm 1.3\end{array}$ & $\begin{array}{l}105.16 \\
\text { NT }\end{array}$ \\
\hline $\begin{array}{l}\text { C. coli (NCTC 12525) } \\
\text { Streptomycin }\end{array}$ & $\begin{array}{l}\text { NA } \\
21.7 \pm 1.6\end{array}$ & $\begin{array}{l}11.8 \pm 1.1 \\
24.8 \pm 0.7\end{array}$ & $\begin{array}{l}17.2 \pm 1.3 \\
28.8 \pm 1.3\end{array}$ & $\begin{array}{l}219.88 \\
\text { NT }\end{array}$ \\
\hline
\end{tabular}

aNA: No activity, ${ }^{\text {b: }}$ Standard antibiotic, ${ }^{\mathrm{c}}$ : Not tested

Although the same MIC values were reported for essential oils against different strains in literatue, in this study differences in MIC values were found against the clinical and standard strains of Campylobacter. In literature, different MIC values were reported. Antibacterial and antifungal activities of essential oils of twelve Ocimum basilicum L. cultivars which were grown in Serbia were investigated by Beatovic et al. ${ }^{26}$. However, lower MIC values than current study were reported, they were ranging from 0.009-11.74 $\mu \mathrm{g} / \mathrm{mL}$. Silveira et al. ${ }^{27}$, reported MIC values from 0.075 to $2.5 \mu \mathrm{g} / \mathrm{mL}$ against $S$. aureus, $L$. monocytogenes, $B$. cereus, Yersinia enterocolitica, E. coli and $S$. typhimurium. In another study, mean MIC values were detected as 0.75 and $0.73 \mu \mathrm{g} / \mathrm{mL}$ against 6 gram positive and 12 gram negative bacteria respectively ${ }^{21}$. Higher MIC values were also repor- 
ted for gram positive bacteria as $18-36 \mu \mathrm{g} / \mathrm{mL}$, and for gram-negative bacteria as $9-18 \mu \mathrm{g} / \mathrm{mL}^{28}$. By the existence of different EO components with respect to harvesting season differences as well as extraction method, different antimicrobial activity levels can be obtained. These differences may be due to this fact ${ }^{15}$.

Antimicrobial spectrum of basil essential oil was reported as restricted to specific bacteria as Staphylococcus spp., Enterococcus spp., E. coli, P. aeruginosa, Acinetobacter baumannï, Aeromonas hydrophila, B. cereus, Bacillus subtilis, Enterobacter spp., Listeria spp., Proteus spp., Salmonella spp., Serratia marcescens, and $Y$. enterocolitica and fungi as Candida spp., Rhodotorula spp., and Saccharomyces cerevisae ${ }^{8}$. Although basil essential oil has restricted antimicrobial activity, in current study it has also been proven that it has antimicrobial activity against Campylobacter spp.

This study described antibacterial efficiency differences of basil essential oil against clinical and standard isolates of Campylobacter spp., as well as the chemical composition of corresponding essential oil. The results indicated that tested EO has varying degree of antibacterial efficiency against both $C$. jejuni and $C$. coli isolates. However, with in vitro experiments, in vivo studies are also required because antimicrobial effect showed differences even between clinical and standard strains. In addition, optimum essential oil concentration should be determined to ensure antimicrobial activity and acceptable sensorial properties.

\section{ACKNOWLEDGEMENTS}

The authors wish to thank Anadolu University, Medicinal Plants, Drugs and Scientific Research Center for GC and GC-MS analyses of basil essential oil. This research was supported by Istanbul Technical University, Scientific Research Projects (Project no, 38819).

\section{REFERENCES}

1. WHO. The Global View of Campylobacteriosis, Report of an expert Consultation. Utrecht, Netherlands, 2002.

2. Nachamkin, I.; Szymanski, C. M.; Blaser M. J. Campylobacter (No. Ed. 3). ASM Press. ProQuest Ebook Central, 2oo8, 54.

3. Moore J. E; Barton, M. D., Blair, I. S., Corcoran, D., Dooley, J. S., Fanning S., Kempf, I.; Lastovica, A. J.; Lowery, C. J.; Matsuda, M.; McDowell, D.A.; McMahon, A.; Millar, B. C.; Rao, J. R.; Rooney, P. J.; Seal, B. S.; Snelling, W. J.; Tolba, O. The epidemiology of antibiotic resistance in Campylobacter. Microbes Infect, 2oo6, 8, 1955-1966.

4. Swamy, M. K.; Akhtar, M. S.; Sinniah, U. R. Antimicrobial properties of plant essential oils against human pathogens and their mode of action: an updated review. Evid Based Complement Alternat Med, 2016, 3012462. 
5. Mutlu-Ingok, A.; Karbancioglu-Guler, F. Cardamom, Cumin, and Dill Weed Essential Oils: Chemical Compositions, Antimicrobial Activities, and Mechanisms of Action against Campylobacter spp. Molecules, 2017, 22, 1191.

6. Joshi, R. K. Role of Natural Products against Microorganisms. Am J Clin Microbiol Antimicrob., 2018, 1, 1005 .

7. Chouhan, S.; Sharma, K.; Guleria, S. Antimicrobial Activity of Some Essential OilsPresent Status and Future Perspectives. Medicines, 2017, 4, 58.

8. Sakkas, H.; Papadopoulou, C. Antimicrobial Activity of Basil, Oregano, and Thyme Essential Oils. J Microbiol Biotechnol, 2017, 28, 429-438.

9. Smith-Palmer, A.; Stewart, J.; Fyfe, L. Antimicrobial properties of plant essential oils and essences against five important food-borne pathogens. Lett Appl Microbiol, 1998, 26, $118-122$.

10. Friedman, M.; Henika, P. R.; Mandrell, R. E. Bactericidal activities of plant essential oils and some of their isolated constituents against Campylobacter jejuni, Escherichia coli, Listeria monocytogenes, and Salmonella enterica. J Food Protect, 2002, 65, 1545-1560.

11. Şaml, A.; Ayaş, R.; Ülger, N. Akut bakteriyel gastroenterit etkenleri arasında Campylobacter turlerinin yeri ve antibiyotiklere duyarlılıkları. 'Ulusal Klinik Mkrobiyoloji Kongresi, 2013, 408.

12. Deans, S.; Ritchie, G. Antimicrobial properties of plant essential oils. Int J Food Microbiol, 1987, 5, 165-180.

13. Wiegand, I.; Hilpert, K.; Hancock, R. E. W. Agar and broth dilution methods to determine the minimal inhibitory concentration (MIC) of antimicrobial substances. Nat. Protoc. 2oo8, $3,163^{-175}$.

14. Stepanović, S.; Antić, N.; Dakić, I.; Švabić-Vlahović, M. In vitro antimicrobial activity of propolis and synergism between propolis and antimicrobial drugs. Microbiol Res, 2003, 158, 353-357.

15. Burt, S. Essential oils: Their antibacterial properties and potential applications in foods-a review. Int $J$ Food Microbiol, 2004, 94, 223-253.

16. Telci, I.; Bayram, E.; Yllmaz, G.; Avcı, B. Variability in essential oil composition of Turkish basils (Ocimum basilicum L.). Biochem. Syst. Ecol., 2006, 34, 489-497.

17. Hussain, A. I.; Anwar, F.; Sherazi, S. T. H.; Przybylski, R. Chemical composition, antioxidant and antimicrobial activities of basil (Ocimum basilicum) essential oils depends on seasonal variations. Food Chem., 2oo8, 108, 986-995.

18. Chowdhury, J. U.; Bhuiyan, M. N. H.; Saha, G. C.; Nada, K.; Rahim, M. Compositions of the essential oils from two types of ocimum basilicum introduced in Bangladesh. Bangladesh $J$ Sci Ind Res, 2013, 48, 217-220.

19. Yayi, E.; Moudachirou, M.; Chalchat, J. C. Chemotyping of three Ocimum species from Benin: O. basilicum, O. canum and O. gratissimum. $J$ Essent Oil Res., 2001, 13, 13 -17.

20. Vieira, R. F.; Simon, J. E. Chemical characterization of basil (Ocimum spp.) found in the markets and used in traditional medicine in Brazil. Econ Bot., 200o, 54, 207-216.

21. Gaio, I.; Saggiorato, A. G.; Treichel, H.; Cichoski, A. J.; Astolfi, V.; Cardoso, R. I.; ... \& 
Cansian, R. L. Antibacterial activity of basil essential oil (Ocimum basilicum L.) in Italiantype sausage. $J$ Verbrauch Lebensm, 2015, 10, 323-329.

22. Predoi, D.; Iconaru, S. L.; Buton, N.; Badea, M. L.; Marutescu, L. Antimicrobial Activity of New Materials Based on Lavender and Basil Essential Oils and Hydroxyapatite. Nanomaterials, 2018, 8, 291.

23. Kaya, I.; Yigit, N.; Benli, M. Antimicrobial activity of various extracts of Ocimum basilicum L. and observation of the inhibition effect on bacterial cells by use of scanning electron microscopy. Afr $J$ Tradit Complement Altern Med., 2oo8, 5, 363-369.

24. Suppakul, P.; Miltz, J.; Sonneveld, K.; Bigger, S. W. Antimicrobial properties of basil and its possible application in food packaging. J. Agric. Food Chem., 2003, 51, 3197-3207.

25. Luber, P.; Bartelt, E.; Genschow, E.; Wagner, J.; Hahn, H. Comparison of broth microdilution, E Test, and agar dilution methods for antibiotic susceptibility testing of Campylobacter jejuni and Campylobacter coli. J. Clin. Microbiol., 2003, 41, 1062-1068.

26. Beatovic, D.; Krstic-Milosevic, D.; Trifunovic, S.; Siljegovic, J.; Glamoclija, J.; Ristic, M.; Jelacic, S. Chemical composition, antioxidant and antimicrobial activities of the essential oils of twelve Ocimum basilicum L. cultivars grown in Serbia. Records of Natural Products, 2015, 9,62 .

27. Silveira, S. M. D.; Cunha Júnior, A.; Scheuermann, G. N.; Secchi, F. L.; Vieira, C. R. W. Chemical composition and antimicrobial activity of essential oils from selected herbs cultivated in the South of Brazil against food spoilage and foodborne pathogens. Ciência Rural, 2012, 42, 1300-1306.

28. Moghaddam, A. M. D.; Shayegh, J.; Mikaili, P.; Sharaf, J. D. Antimicrobial activity of essential oil extract of Ocimum basilicum L. leaves on a variety of pathogenic bacteria. $J$. Med. Plants Res., 2011, 5, 3453-3456. 